\title{
Screening Cabbage Cultivars for Resistance to Black Rot under Field Conditions
}

\author{
Andre Luiz Biscaia Ribeiro da Silva ${ }^{1}$, Joara Secchi Candian ${ }^{1}$, \\ Elizanilda Ramalho do Rego ${ }^{1,2}$, Timothy Coolong ${ }^{1}$, \\ and Bhabesh Dutta ${ }^{3}$
}

AdDitional INDEX wORDs. Brassica olevacea var. capitata, disease severity, head quality, Xanthomonas campestris pv. campestris, yield

SUMmaRY. The use of resistant cultivars against Xanthomonas campestris pv. campestris $(X c c)$ is considered a critical management practice for black rot (BR) management in cabbage (Brassica oleracea var. capitata). Although most studies that have evaluated resistance to BR were conducted in greenhouses without accounting for yield, there is a clear need to investigate cultivar performance under field conditions. The objectives of this study were to evaluate commercial cabbage cultivars for resistance to BR and determine yield and head quality under field conditions. Field experiments with eight cultivars (Acclaim, Bravo, Capture, Celebrate, Cheers, Melissa, Monterey, and TCA-549) were conducted in two cabbage growing seasons, Fall 2018 and Spring 2019. Fields were spray-inoculated with $X c c\left(3 \times 10^{5} \mathrm{cfu} / \mathrm{mL}\right)$ at 35 and 49 days after transplanting in Fall 2018 and Spring 2019, respectively. Cabbage BR severity was evaluated at weekly intervals starting from 7 days postinoculation (DPI) until harvest. Marketable and unmarketable yields and cabbage head quality were measured at harvest. Cabbage BR symptoms were detected in all tested cultivars for both growing seasons with initial symptoms observed as early as 28 and 21 DPI in Fall 2018 and Spring 2019, respectively. Severity of cabbage BR at harvest was significantly greater in Fall 2018 compared with Spring 2019, whereas marketable yield was significantly higher in Spring 2019 (45,169 lb/acre) compared with Fall 2018 (26,370 lb/acre). In both growing seasons, 'TCA-549' had the lowest severity of BR and 'Melissa' had the highest severity of BR. Area under the disease progress curve (AUDPC) was 175 and 13 for 'TCA-549' in Fall 2018 and Spring 2019, respectively. The AUDPC for 'Melissa' in Fall 2018 and Spring 2019 were 2376 and 905, respectively. Regardless of growing season, cabbage marketable yield was higher for 'Acclaim' (51,760 $\mathrm{lb} /$ acre) compared with all other cultivars; however, there was no significant difference between Acclaim and TCA-549 (42,934 lb/acre) for cabbage marketable yield. Cabbage marketable yield was the lowest for cultivars Melissa (18,275 lb/acre) and Capture (24,236 $\mathrm{lb} / \mathrm{acre})$. Overall, there was a significant correlation between BR disease severity and cabbage marketable and unmarketable yields. Increasing the BR severity decreased cabbage marketability due to an increase in unmarketable yields. Continued development of cultivar resistance to BR is important for cabbage production in the southeastern United States, given the favorable conditions for disease development. The use of cultivars with low susceptibility, pathogen-free seeds, crop rotation, and proper spraying programs should be considered the best management practice for BR disease.

G eorgia is a leading producer of fresh market cabbage (Brassica olevacea var. capitata) in the United States, with an annual

Received for publication 2 Dec. 2019. Accepted for publication 27 Feb. 2020.

Published online 24 March 2020

${ }^{1}$ Department of Horticulture, University of Georgia, 2360 Rainwater Road, Tifton, GA 31793

${ }^{2}$ Department of Basic and Social Science, Federal University of Paraiba, Areia, Brazil

${ }^{3}$ Department of Plant Pathology, University of Georgia, 2360 Rainwater Road, Tifton, GA 31793

A.L.B.R.d.S. is the corresponding author. E-mail: adasilva@uga.edu.

This is an open access article distributed under the $\mathrm{CC}$ BY-NC-ND license (https://creativecommons.org/ licenses/by-nc-nd/4.0/).

https://doi.org/10.21273/HORTTECH04481-19 production of 8577 acres valued in more than $\$ 53$ million (Wolfe and Stubbs, 2018). Annual losses due to diseases for cabbage grown in Georgia are estimated to range from $\$ 1$ million to \$3 million (Little, 2019).
BR of cabbage caused by Xanthomonas campestris pv. campestris $(X c c)$ is one of the major disease issues for cabbage production in Georgia. Symptoms of BR on cabbage are characterized by V-shaped chlorotic lesions at the leaf margin, followed by necrosis and darkened veins that consequently reduce movement of water and nutrients through xylem tissues, reducing cabbage yield and head quality (Vicente and Holub, 2013). Under severe BR outbreaks, the bacterium can infect the developing cabbage head, resulting in head rot.

The growth of $X c c$ is favored by warm and humid weather conditions with optimal temperatures for growth of 77 to $86^{\circ} \mathrm{F}$ (Meenu et al., 2013; Williams, 1980). Therefore, the high temperatures and frequent rainfall events in the southeastern United States are favorable for the disease (Vicente and Holub, 2013). Growers usually use rigorous spray programs to reduce yield losses while adopting best management practices to reduce disease incidence. The bacterium can be seedborne and seed-transmitted or can survive on crop residue and on cruciferous (Brassicaceae) weeds (Cook et al., 1952; Lema et al., 2011; Vicente et al., 2001). Copper-based bactericides are generally used for BR control, but under favorable conditions for the disease, it is difficult to manage even with a rigorous bactericide spray program.

Although improved cultural practices including irrigation scheduling and crop rotation are suggested to reduce the spread of $X c c$ in the field (Arias et al., 2000; Roberts et al., 2007), cultivar resistance is still considered the most effective method to manage BR (Afrin et al., 2018; Krauthausen et al., 2011; Roberts and Koenraadt, 2006; Schaad and Alvarez, 1993; Taylor et al., 2002). Cultivar resistance against $X c c$ in cabbage has been investigated previously; however, many recent studies have been

\begin{tabular}{llll}
\hline $\begin{array}{l}\text { Units } \\
\text { To convert U.S. to } \\
\text { SI, multiply by }\end{array}$ & U.S. unit & SI unit & $\begin{array}{l}\text { To convert SI to } \\
\text { U.S., multiply by }\end{array}$ \\
\hline 29,574 & $\mathrm{fl} \mathrm{oz}$ & $\mu \mathrm{L}$ & $3.3814 \times 10^{-5}$ \\
29.5735 & $\mathrm{fl} \mathrm{oz}$ & $\mathrm{mL}$ & 0.0338 \\
0.3048 & $\mathrm{ft}$ & $\mathrm{m}$ & 3.2808 \\
2.54 & inch $(\mathrm{es})$ & $\mathrm{cm}$ & 0.3937 \\
645.1600 & inch & $\mathrm{mm}^{2}$ & 0.0016 \\
0.4536 & $\mathrm{lb}$ & $\mathrm{kg}$ & 2.2046 \\
1.1209 & $\mathrm{lb} / \mathrm{acre}$ & $\mathrm{kg} \cdot \mathrm{ha}^{-1}$ & 0.8922 \\
1 & $\mathrm{ppm}$ & $\mathrm{mg} \cdot \mathrm{L}^{-1}$ & 1 \\
$\left({ }^{\circ} \mathrm{F}-32\right) \div 1.8$ & ${ }^{\circ} \mathrm{F}$ & ${ }^{\circ} \mathrm{C}$ & $\left({ }^{\circ} \mathrm{C} \times 1.8\right)+32$
\end{tabular}


focused on the seedling stage of plants grown under greenhouse conditions (Afrin et al., 2018; Peňázová et al., 2018; Saha et al., 2016; Taylor et al., 2002). Some studies have been conducted in mature plants under field conditions, but these have generally not recorded the impact of BR on yields (Griffiths and Roe, 2005; Jensen et al., 2005; Kocks and Ruissen, 1996; Massomo et al., 2004). Kocks and Ruissen (1996) evaluated BR disease in cabbage development as affected by spatial and temporal gradients under field conditions. The authors observed that temporal and spatial progression of BR was reduced in resistant ('Roxy') compared with intermediately resistant ('Erdeno' and 'Bartolo') and susceptible ('Perfect Ball') cultivars. Later, Griffiths and Roe (2005) evaluated the response of several cabbage cultivars and breeding lines for BR resistance with different inoculation methods in the northeastern United States. The authors identified five resistant breeding lines (Badger\#16, Cornell 101, Cornell 102, NY 4002, and PI 4266606) and one commercial resistant cultivar (Silver Dynasty); however, yield response was not considered. Because BR can also cause significant yield reductions under favorable conditions (Shimelis, 2005; Williams, 1980), yield response to infection should be considered during screening for resistance in field. Thus, the objective of this study was to evaluate commercial cabbage cultivars for resistance to BR and to estimate yield and head quality under field conditions in the southeastern United States.

\section{Material and methods}

Field experiments were conducted during Fall 2018 and Spring 2019 at the University of Georgia, Horticultural Research Farm, Tifton (lat. $31.4718^{\circ} \mathrm{N}$, long. $83.5303^{\circ} \mathrm{W}$ ). Soil in the experimental area is classified as Tifton loamy sand; soil with a $2 \%$ slope and low water holding capacity (U.S. Department of Agriculture, 2019). Climate in the region is classified as Cfa (humid subtropical climate), characterized by high temperatures with precipitation during the summer and cool dry periods during the winter (Köppen, 1931). Rainfall and maximum and minimum air temperatures were measured hourly by the automated weather station from the Georgia Automated Environmental Monitoring Network
[University of Georgia Weather Network, Tifton Station, Tifton, GA (University of Georgia, 2019)].

EXPERIMENTAL DESIGN AND CROP MANAGEMENT. A randomized complete block design $(r=4)$ was used with eight commercial cabbage cultivars, which were replicated in two consecutive growing seasons (i.e., Fall 2018 and Spring 2019), leading to the analysis of growing season as a repeated measures design.

Cabbage seeds of 'Acclaim', 'Bravo', 'Capture', 'Celebrate', 'Cheers', 'Melissa', 'Monterey', and 'TCA-549' were planted into 200-cell trays filled with soilless media (Pro-Mix BX; Premier Tech, Riviere-du-Loup, QC, Canada) on 15 Aug. 2018 and 10 Jan. 2019. Seedlings were greenhouse grown with temperature set points of $80 / 70{ }^{\circ} \mathrm{F}$ (day/night). Plants were watered daily as needed and fertilized every other day after germination with a $171 \mathrm{mg} \cdot \mathrm{L}^{-1}$ nitrogen $(\mathrm{N})$ solution $(20 \mathrm{~N}-8.7 \mathrm{P}-$ 16.6K; Pro Sol, PS, Ozark, AL) until transplanting. Seedlings were transplanted on 1 Oct. 2018 and 21 Feb. 2019. Transplants were planted on 6inch-tall raised beds spaced 6 - $\mathrm{ft}$ center to center. Raised beds were planted with double rows spaced 18 inches apart within each bed with 8 -inch in-row spacing for a plant population of 21,780 plants/acre. Experimental plots comprised 40 cabbage plants. Adjacent plots within a bed were separated by a 5-ft buffer.

After formation of plant beds, $0.5 \mathrm{lb} /$ acre oxyfluorfen (Goal 2XL; Dow AgroSciences, Indianapolis, IN) was applied $3 \mathrm{~d}$ before transplanting for weed suppression in both growing seasons. After transplant establishment, weekly applications of $0.133 \mathrm{lb} /$ acre cyantraniliprole (Exirel; DuPont, Wilmington, DE) rotated with 0.18 lb/acre flupyradifurone (Sivanto; Bayer CropScience, Research Triangle Park, NC) were applied for insect control. No fungicides or bactericides were used in either studied season to avoid an impact on $X c c$.

Cabbage was fertilized at $50 \mathrm{lb} /$ acre N [10N-4.4P-8.3K(Super Rainbow, Agrium U.S. Inc., Loveland, $\mathrm{CO})$ ] during bed formation and at $21 \mathrm{~d}$ after transplanting (DAT) in both years. In addition, two fertilizer applications of $60 \mathrm{lb} /$ acre $\mathrm{N}[15.5 \mathrm{~N}-$ 0P-0K (Calcium Nitrate-YaraLiva; Yara North America, Tampa, FL)] at 42 and 56 DAT in Fall 2018 and 47 and 62 DAT in Spring 2019 were performed. A total of $220 \mathrm{lb} /$ acre $\mathrm{N}$, $100 \mathrm{lb} /$ acre P, and $100 \mathrm{lb} /$ acre K were applied throughout crop development.

Irrigation water was overhead applied. Water was applied daily at an irrigation depth of 0.2 inch for a 20 $\mathrm{d}$ period after transplanting to ensure plant establishment. After this point, water was applied every $2 \mathrm{~d}$ according to the historical crop evapotranspiration for cabbage (da Silva et al., 2019). In the case of rainfall events, irrigation was suspended and resumed after $3 \mathrm{~d}$.

BR DISEASE. In both growing seasons, entire cabbage plants were spray-inoculated with a bacterial suspension $\left(3 \times 10^{5} \mathrm{cfu} / \mathrm{mL}\right)$ using a backpack sprayer until runoff. The $X c c$ strain (Xcc 00-1) used in this study was previously isolated from infected cabbage foliage in Georgia. Plant inoculation was conducted at 35 and 49 DAT in Fall 2018 and Spring 2019, respectively. Severity of BR ratings was conducted at weekly intervals starting from 7 DPI and were performed until harvest. In each screening, an overall score of BR severity was assigned for each plot using the disease severity ratings proposed by Vicente et al. (2002), where $0 \%=$ no visible symptoms; $10 \%=$ small necrosis or chlorosis near the inoculation point; $30 \%=$ typical small $\mathrm{V}$-shaped lesion with black veins; $50 \%=$ typical lesion half way to the middle vein; $70 \%=$ typical lesion succeeding to the middle vein; $90 \%=$ lesions reaching the middle vein.

To confirm putative BR symptoms on cabbage leaves in both growing seasons, isolations were conducted on semiselective agar medium using small $\left(\approx 4 \mathrm{~mm}^{2}\right)$ pieces of leaf tissue along lesion margins collected from all plots at harvesting. Tissues were excised and chopped in $100 \mu \mathrm{L}$ of phosphatebuffered saline followed by streaking on yeast dextrose carbonate agar medium. After $5 \mathrm{~d}$ of incubation at $82^{\circ} \mathrm{F}$, yellow-colored colonies were tentatively identified as $X c c$ colonies. Confirmation of bacterial identity was achieved by extracting genomic DNA from two colonies per isolation and amplifying them with a polymerase chain reaction assay using $X c c$-specific primers (Park et al., 2004).

The AUDPC, which characterizes the progress of cabbage BR, was calculated from disease severity ratings taken on $0,7,14,21,28,35,58$, 64, and 69 DPI in Fall 2018 and 0, 6, 
$13,20,27,34,41$, and 49 DPI in Spring 2019. The AUDPC values were calculated for each plot by the method described by Campbell and Madden (1990) as follows:

$$
A U D P C=\sum_{i=2}^{n}\left[\left(y_{i}+y_{i-1}\right) / 2\right]\left(t_{i}-t_{i-1}\right)
$$

where $y_{i}$ is the BR severity score at $i^{\text {th }}$ evaluation, $t$ is the DPI of the $i^{t h}$ evaluation, and $n$ is the number of BR severity evaluations.

Cabbage harvesting. Cabbage heads were harvested twice in each growing season. The first harvest was carried out when $\approx 50 \%$ of heads reached marketable size on 104 and 91 DAT of Fall 2018 and Spring 2019 , respectively. The second harvest occurred on 110 DAT for Fall 2018 and 98 DAT for Spring 2019, when remaining heads in the field were considered marketable. Cabbage heads were harvested by cutting the stem at the soil surface and removing wrapper leaves. Heads were classified as marketable for the fresh market when trimmed head weights were greater than $2 \mathrm{lb}$. Heads with physical damage, disease symptoms, and weights below $2 \mathrm{lb}$ were considered unmarketable. Marketable and unmarketable yield were then extrapolated to a per acre base using the cabbage plant population. In addition, a total of five marketable cabbage heads per plot were randomly selected for internal quality evaluation at first harvest of both growing seasons. Measurements of cabbage head polar (height) and equatorial (width) diameter, and core height and core base width were recorded.

Statistical analysis. Statistical analyses were performed using generalized linear mixed techniques as implemented in SAS PROC GLIMMIX (SAS/STAT 14.2; SAS Institute, Cary, NC), which are useful for the analysis of repeated measurements of the same experimental units (Bowley, 2015). Cabbage BR severity was analyzed with growing season, cabbage cultivar, sampling time, and their interactions as fixed effects. Location in the field (block) was considered a random effect, and sampling timing and growing season were treated as repeated measurements. The AUDPC of cabbage BR, marketable and unmarketable yield, as well as head height, head diameter, core height, and core width were analyzed with growing season, cabbage cultivar, and their interaction as fixed effects. Location in the field (block) was also considered a random effect, and growing season was treated as a repeated measurement. All analyses had the heterogeneous compound symmetry as the covariance structure with the smallest Akaike's
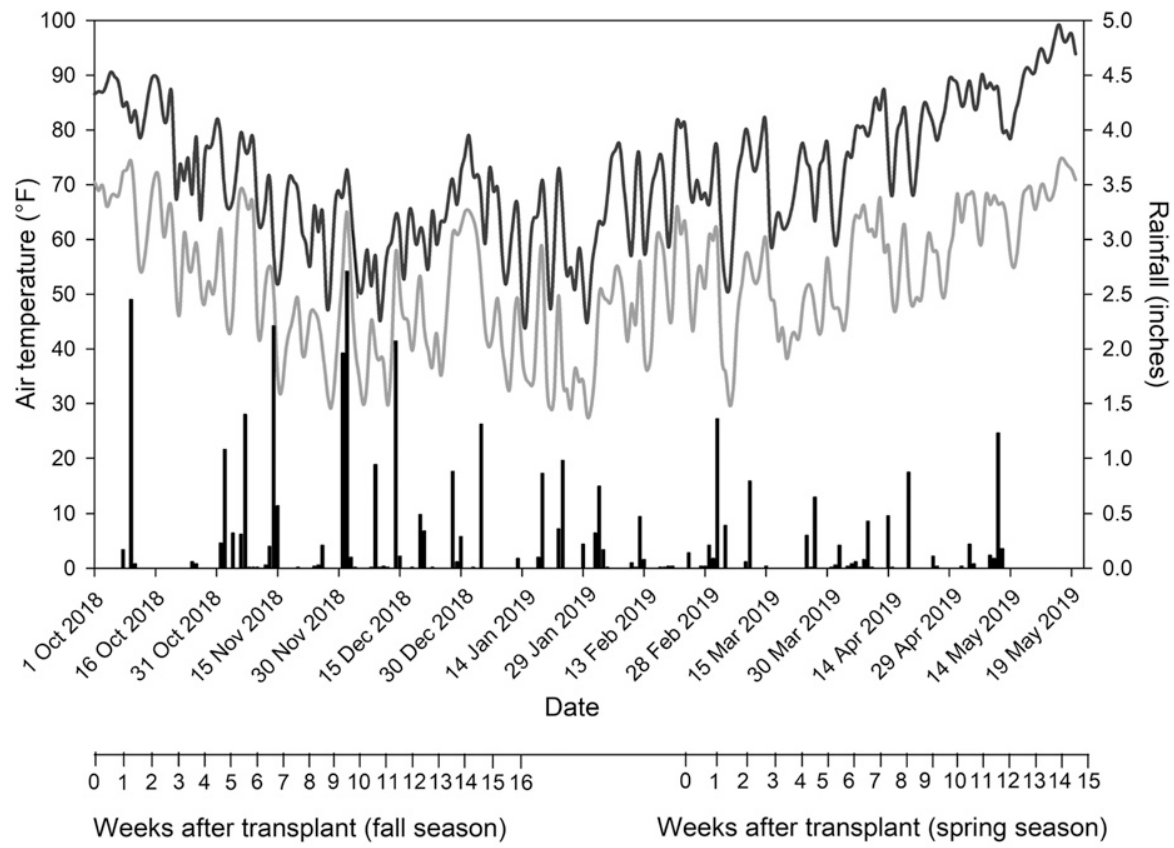

- Maximum temperature - Minimum temperature Rainfall

Fig. 1. Weather conditions for Fall 2018 and Spring 2019, including maximum and minimum air temperature and rainfall events. Data recorded at $\mathbf{l}-\mathrm{h}$ intervals and retrieved from the Georgia Automated Environmental Monitoring Network at Tifton; $\left({ }^{\circ} \mathrm{F}-32\right) \div 1.8={ }^{\circ} \mathrm{C}, 1$ inch $=2.54 \mathrm{~cm}$.

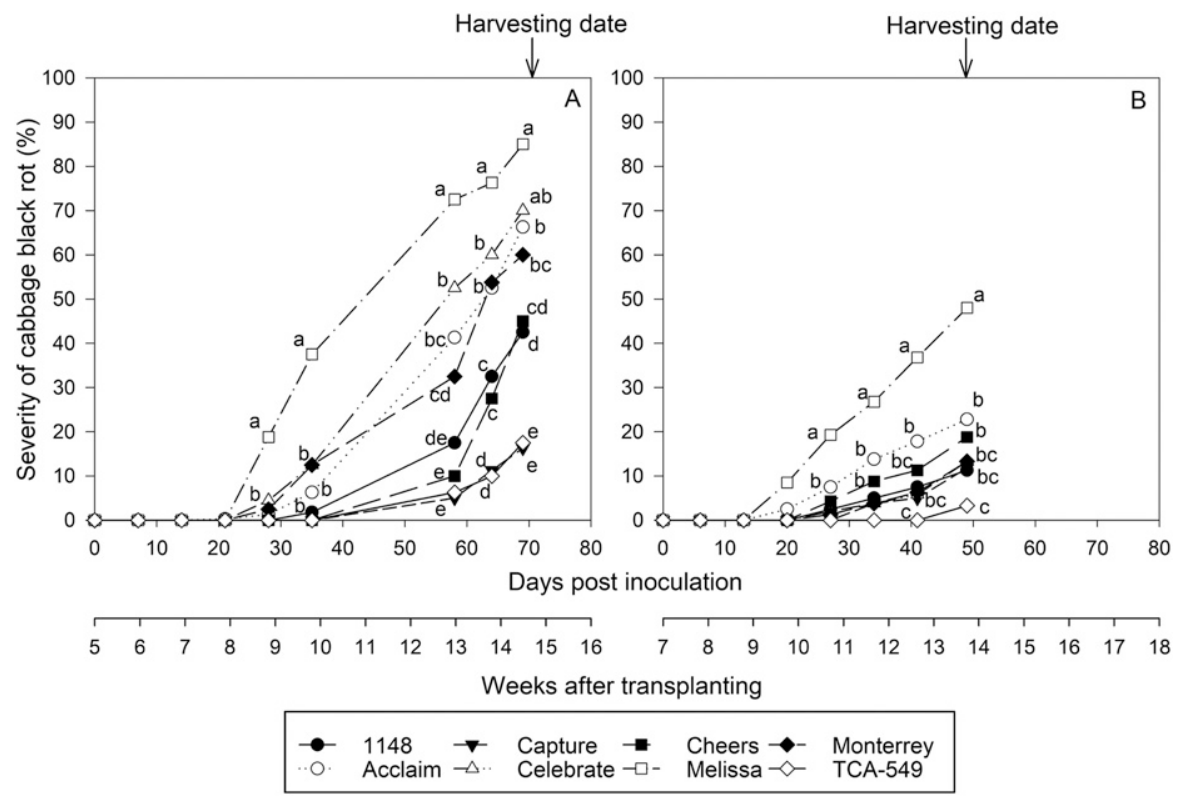

Fig. 2. Severity of cabbage black rot per cultivar during the crop development in Fall 2018 (A) and Spring 2019 (B). Values followed by same letters within each day after inoculation or week after transplanting indicate no significant difference $(P \leq 0.05)$ among cabbage cultivars according to Tukey-Kramer adjustment. 
information. Least square means comparisons were performed using the Tukey-Kramer adjusted probability value of 0.05 , and means were portioned using the SLICE command in SAS.

Cabbage marketable yield, unmarketable yield, head height, and head diameter were correlated with cabbage BR disease severity at harvest using the SAS PROC CORR (SAS/ STAT 14.2). Correlations were considered significant at a probability value of 0.05 , and the Pearson coefficient was selected to determine the strength of correlation.

\section{Results}

WEATHER CONDITIONS. Rainfall accumulation was greater in Fall 2018 (20.9 inches) compared with Spring 2019 (8.4 inches). Historical crop evapotranspiration (2000-17) for cabbage in the same period averaged 4.8 and 11.8 inches for fall and spring, respectively. During Fall 2018, daily air temperatures decreased with crop development, while daily air temperature increased with crop development for Spring 2019 (Fig. 1). Daily average air temperatures were 59 and $67^{\circ} \mathrm{F}$ for Fall 2018 and Spring 2019 seasons, respectively.

Cabbage BR disease Severity. Growing season, sampling time, and cultivar significantly interacted to affect BR severity in cabbage (Fig. 2). In Fall 2018 (Fig. 2A), cabbage BR symptoms were initially observed at 28 DPI, and cabbage BR severity was less than $10 \%$ for all cultivars except for Melissa, which had a severity of 19\%. Similarly, cabbage BR severity measured at 35 DPI, was significantly greater in 'Melissa' $(37.5 \%)$, compared with all other cultivars (4.7\%). At harvest, the cultivar Melissa had a BR severity of $85 \%$, although this was not significantly different from 'Celebrate', which had a BR severity of $70 \%$. Cultivars TCA-549 and Capture had the lowest cabbage BR severity at harvest, averaging $16 \%$ and $18 \%$, respectively (Fig. 2A). Representations of visual symptoms of BR at harvest in Fall 2018 for each cultivar are shown in Fig. 3.

In Spring 2019, symptoms of BR were first recorded at 21 DPI (Fig. 2B). At this time, the severity of BR was low in all cabbage cultivars, and significant differences were not detected. At 27 DPI, there were significant differences in BR severity among cultivars (Fig. $2 \mathrm{~B})$. As in Fall 2018, the cultivar Melissa had the highest cabbage BR severity rating (19.3\%) in Spring 2019 , while the average of all other cultivars was $2.5 \%$. At harvest, 'Melissa' had the highest BR severity (48\%), while the cultivar TCA-549 (3.3\%) had the lowest severity of BR. Cabbage BR severity at harvest for 'TCA-549' was not significantly different from 'Bravo', 'Capture', 'Celebrate', and 'Monterey' in Spring 2019.

Growing season and cultivar significantly affected the AUDPC for BR (Table 1). In Fall 2018, 'Melissa' had the highest AUDPC (2376), which was significantly greater than all other cultivars. The lowest numerical AUDPC in Fall 2018 were in
'Capture' and 'TCA-549', which averaged 189 and 175 , respectively. The cultivar Celebrate had an AUDPC of 408 and had no significant difference from Capture and TCA-549 in Fall 2018. In Spring 2019, 'Melissa' had the highest AUDPC (905), whereas 'TCA-549' had the lowest numerical AUDPC and was not significantly different from 'Capture', 'Celebrate', 'Bravo', 'Monterey', and 'Cheers'. The effect of growing season within cultivar was significant for all cultivars, except for Capture and TCA-549. In general, the AUDPC of cabbage BR was higher in Fall 2018 compared with Spring 2019.

Cabbage Yield. Growing season and cultivar did not significantly interact to affect cabbage marketable

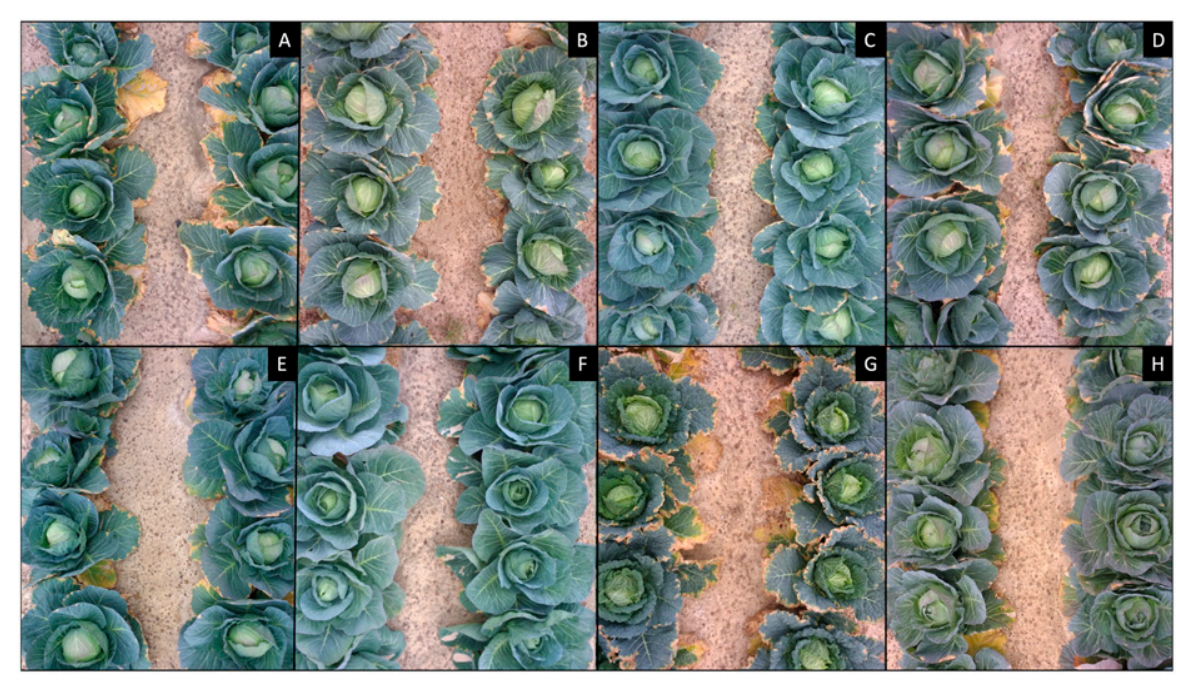

Fig. 3. Visual symptoms of cabbage black rot at harvest time for cultivars Monterey (A), Cheers (B), Acclaim (C), Celebrate (D), Bravo (E), Capture (F), Melissa (G), and TCA-549 (H) evaluated in Fall 2018 at Tifton, GA.

Table 1. Effects of the interaction of growing season (i.e., Fall 2018 and Spring 2019) and cabbage cultivar on the area under the disease progress curve (AUDPC) for cabbage black rot at Tifton, GA.

\begin{tabular}{lcc}
\hline & \multicolumn{3}{c}{ Season } \\
\cline { 2 - 3 } Cultivar & Fall $\mathbf{2 0 1 8}$ & Spring 2019 \\
\cline { 2 - 3 } Melissa & $2,376 \mathrm{a} \mathrm{A}^{\mathrm{z}}$ & AUDPC \\
Cheers & $1,495 \mathrm{~b} \mathrm{~A}$ & $905 \mathrm{a} \mathrm{B}$ \\
Acclaim & $1,158 \mathrm{c} \mathrm{A}$ & $250 \mathrm{bc} \mathrm{B}$ \\
Monterey & $1,121 \mathrm{c} \mathrm{A}$ & $406 \mathrm{~b} \mathrm{~B}$ \\
Bravo & $565 \mathrm{~d} \mathrm{~A}$ & $134 \mathrm{bc} \mathrm{B}$ \\
Celebrate & $408 \mathrm{de} \mathrm{A}$ & $153 \mathrm{bc} \mathrm{B}$ \\
Capture & $189 \mathrm{e} \mathrm{A}$ & $136 \mathrm{bc} \mathrm{B}$ \\
TCA-549 & $175 \mathrm{e} \mathrm{A}$ & $110 \mathrm{bc} \mathrm{A}$ \\
\hline
\end{tabular}

${ }^{\mathrm{z}}$ Values followed by the same lowercase letter within season (column) indicates no significant differences $(P \leq 0.05)$ among cultivar (row) according to Tukey-Kramer adjustment. Values followed by the same uppercase letter within cultivar (row) indicates no significant differences $(P \leq 0.05)$ among seasons (column) according to Tukey-Kramer adjustment. 
and unmarketable yield; however, the main effects of growing season and cultivar were significant for these yield parameters (Table 2).

Cabbage marketable yield was higher for Spring 2019 compared with Fall 2018 (Table 2). Marketable yield represented $57 \%$ of the total yield in Fall 2018 with an average yield of 26,370 lb/acre. In Spring 2019, marketable yield averaged $45,169 \mathrm{lb} /$ acre and represented $85 \%$ of total yield. In contrast, cabbage unmarketable yield was lower in Spring 2019 $(20,236 \mathrm{lb} / \mathrm{acre})$ compared with Fall 2018 (9358 lb/acre).

There was no significant difference between 'Acclaim' (51,760 lb/ acre) and 'TCA-549' (42,934 lb/ acre) for cabbage marketable yield (Table 2). Cultivars Melissa (18,275 $\mathrm{lb} /$ acre $)$ and Capture $(24,236 \mathrm{lb} /$ acre) had the lowest marketable yields, which represented $46 \%$ and $57 \%$ of their total yields, respectively. 'Melissa' was the only cultivar with marketable yield representing less than $50 \%$ of the total yield. Unmarketable yield was the lowest for 'Acclaim', 'TCA-549', and 'Cheers', with 8149, 12,663, and $12,657 \mathrm{lb} /$ acre respectively. Unmarketable yields were highest for 'Capture' and 'Melissa' with 18,118 and $21,343 \mathrm{lb} /$ acre, respectively.

Cabbage Head Quality. There were no significant effects of growing season, cultivar, or their interaction for core width. Head diameter was significantly affected by cultivar (Table 3 ). Growing season and cultivar significantly interacted to affect head height and core height (Table 4).

The cultivar TCA-549 (6.9 inches) had the largest average head diameter, whereas Melissa (5.7 inches) and Bravo (5.8 inches) had the lowest head diameters (Table 3). Cabbage cultivars Acclaim, Capture, Celebrate, Cheers, and Monterey had no significant differences in head diameter from TCA-549, Melissa, or Bravo.

Cabbage head heights were significantly greater in 'Acclaim' (5.6 inches) and 'Monterey' (5.4 inches) compared with 'Melissa' (4.5 inches) in Fall 2018 (Table 4). Head height was not significantly different in cultivars Capture, Celebrate, Cheers, TCA-549, and Bravo compared with Acclaim and Monterey or Melissa. In Spring 2019, 'Acclaim' (6.6 inches) had the tallest cabbage head and 'TCA-549' (4.8 inches) had the

Table 2. Effect of growing season (i.e., Fall 2018 and Spring 2019), cabbage cultivar, and their interaction on cabbage marketable and unmarketable yield at Tifton, GA.

\begin{tabular}{|c|c|c|}
\hline & Marketable yield & Unmarketable yield \\
\hline & \multicolumn{2}{|c|}{$(\text { lb } / \text { acre })^{z}$} \\
\hline \multicolumn{3}{|l|}{ Season } \\
\hline Fall 2018 & $26,370 b^{y}$ & $20,236 \mathrm{a}$ \\
\hline Spring 2019 & $45,169 \mathrm{a}$ & $9,358 \mathrm{~b}$ \\
\hline$P$ value & $* * *$ & $\star * *$ \\
\hline \multicolumn{3}{|l|}{ Cultivar } \\
\hline Acclaim & $51,760 \mathrm{a}$ & $8,149 \mathrm{~d}$ \\
\hline TCA-549 & $42,934 \mathrm{ab}$ & $12,663 \mathrm{~cd}$ \\
\hline Cheers & $38,837 \mathrm{~b}$ & $12,657 \mathrm{~cd}$ \\
\hline Monterey & $37,468 \mathrm{~b}$ & $17,614 \mathrm{bc}$ \\
\hline Bravo & $37,184 \mathrm{~b}$ & $14,169 \mathrm{bc}$ \\
\hline Celebrate & $35,462 \mathrm{~b}$ & $13,663 \mathrm{bc}$ \\
\hline Capture & $24,236 \mathrm{c}$ & $18,118 \mathrm{ab}$ \\
\hline Melissa & $18,275 \mathrm{c}$ & $21,343 \mathrm{a}$ \\
\hline$P$ value & $* * *$ & $* * *$ \\
\hline \multicolumn{3}{|c|}{ Season $\times$ Cultivar } \\
\hline$P$ value & NS & NS \\
\hline
\end{tabular}

Table 3. Effect of growing season (i.e., Fall 2018 and Spring 2019), cabbage cultivar, and their interaction on cabbage head height, head diameter, core height, and core width at Tifton, GA.

\begin{tabular}{|c|c|c|c|c|}
\hline & Head ht & Head diam & Core ht & Core width \\
\hline & \multicolumn{4}{|c|}{ (inches) $^{\mathrm{z}}$} \\
\hline \multicolumn{5}{|l|}{ Season } \\
\hline Fall 2018 & $-^{y}$ & 6.4 & - & 1.2 \\
\hline Spring 2019 & - & 6.3 & - & 1.3 \\
\hline$P$ value $^{\mathrm{x}}$ & $* * *$ & NS & $* * *$ & NS \\
\hline \multicolumn{5}{|l|}{ Cultivar } \\
\hline Acclaim & - & $6.2 \mathrm{ab}^{\mathrm{x}}$ & - & 1.2 \\
\hline Capture & - & $6.5 \mathrm{ab}$ & - & 1.4 \\
\hline Celebrate & - & $6.1 \mathrm{ab}$ & - & 1.3 \\
\hline Cheers & - & $6.6 \mathrm{ab}$ & - & 1.4 \\
\hline Melissa & - & $5.7 \mathrm{~b}$ & - & 1.1 \\
\hline Monterey & - & $6.7 \mathrm{ab}$ & - & 1.3 \\
\hline TCA-549 & - & $6.9 \mathrm{a}$ & - & 1.2 \\
\hline Bravo & - & $5.8 \mathrm{~b}$ & - & 1.1 \\
\hline$P$ value & $* \star *$ & $* *$ & $* * *$ & NS \\
\hline \multicolumn{5}{|c|}{ Season $\times$ Cultivar } \\
\hline$P$ value & $* * *$ & NS & * & NS \\
\hline
\end{tabular}

shortest (flattest). In Spring 2019, 'Acclaim', 'Cheers', 'Melissa', 'Monterey', and 'Bravo', had greater head heights compared with Fall 2018. Head heights in 'TCA-549', 'Capture', and 'Celebrate' were not significantly affected by growing season.

Core height was significantly greater in 'Monterey' (2.6 inches) compared with 'Acclaim' (1.8 inches), 'Celebrate' (2.0 inches), 'Cheers' (2.1 inches), and 'TCA-549' (2.0 inches) in Fall 2018. 'Acclaim' (2.7 inches), 'Melissa' (2.8 inches), and 'Monterey' (2.9 inches) had a significantly greater core height than 'TCA-549' (1.9 inches) in Spring 2019 (Table 4). In Spring 2019, the core height in 
Table 4. Effects of the interaction of growing season (i.e., Fall 2018 and Spring 2019) and cabbage cultivar on cabbage head height and core height at Tifton, GA.

\begin{tabular}{|c|c|c|}
\hline \multirow[b]{3}{*}{ Cultivar } & \multicolumn{2}{|c|}{ Season } \\
\hline & Fall 2018 & Spring 2019 \\
\hline & \multicolumn{2}{|c|}{ Head ht (inches) ${ }^{\mathrm{z}}$} \\
\hline Acclaim & $5.6 \mathrm{~b} \mathrm{~A}^{\mathrm{y}}$ & 6.6 a A \\
\hline Capture & $5.2 \mathrm{a} \mathrm{AB}$ & $5.9 \mathrm{a} \mathrm{AB}$ \\
\hline Celebrate & $5.1 \mathrm{a} \mathrm{AB}$ & 5.7 a B \\
\hline Cheers & $5.1 \mathrm{~b} \mathrm{AB}$ & $6.2 \mathrm{a} \mathrm{AB}$ \\
\hline Melissa & $4.5 \mathrm{~b} \mathrm{~B}$ & $5.4 \mathrm{a} \mathrm{B}$ \\
\hline Monterey & $5.4 \mathrm{~b} \mathrm{~A}$ & $6.3 \mathrm{a} \mathrm{AB}$ \\
\hline TCA-549 & $5.3 \mathrm{a} \mathrm{AB}$ & 4.8 a C \\
\hline \multirow[t]{2}{*}{ Bravo } & $5.1 \mathrm{~b} \mathrm{AB}$ & $6.1 \mathrm{a} \mathrm{AB}$ \\
\hline & \multicolumn{2}{|c|}{ Core ht (inches) } \\
\hline Acclaim & $1.8 \mathrm{~b} \mathrm{~B}$ & $2.7 \mathrm{a} \mathrm{A}$ \\
\hline Capture & $2.2 \mathrm{a} \mathrm{AB}$ & $2.4 \mathrm{a} \mathrm{AB}$ \\
\hline Celebrate & $2.0 \mathrm{a} \mathrm{B}$ & $2.4 \mathrm{a} \mathrm{AB}$ \\
\hline Cheers & $2.1 \mathrm{a} \mathrm{B}$ & $2.3 \mathrm{a} \mathrm{AB}$ \\
\hline Melissa & $2.3 \mathrm{a} \mathrm{AB}$ & 2.8 a $\mathrm{A}$ \\
\hline Monterey & 2.6 a A & 2.9 a A \\
\hline TCA-549 & $2.0 \mathrm{a} \mathrm{B}$ & 1.9 a B \\
\hline Bravo & $2.1 \mathrm{a} \mathrm{AB}$ & $2.4 \mathrm{a} \mathrm{AB}$ \\
\hline
\end{tabular}

${ }^{\mathrm{z}} 1$ inch $=2.54 \mathrm{~cm}$.

${ }^{\mathrm{y}}$ Values followed by the same lowercase letter within cultivar (row) indicates no significant differences $(P \leq 0.05)$ among seasons (column) according to Tukey-Kramer adjustment. Values followed by the same uppercase letter within season (column) indicates no significant differences $(P \leq 0.05)$ among cultivars (row) according to TukeyKramer adjustment.

'Acclaim' was 2.7 inches, which was significantly greater than in Fall 2018 (1.8 inches). There were no significant differences in core height between growing seasons for any other cultivar (Table 4).

Effects of BR on cabbage YIELD AND HEAD QUALITY. Cabbage marketable yield significantly decreased with an increase in cabbage BR severity [Pearson coefficient $=-0.4443$ (Fig. 4A)], whereas cabbage unmarketable yield significantly increased with increasing BR severity [Pearson coefficient $=0.5168$ (Fig. 4B) $]$. Cabbage head height was significantly and negatively correlated with BR severity at harvest [Pearson coefficient $=-0.4049$ (Fig. 4C)]. There was no significant correlation between head diameter and cabbage BR severity $[P=0.065$ (Fig. $4 \mathrm{D})$ ]. However, the negative correlation between BR and head height suggests that marketable heads decreased in size with an increase in BR severity.

\section{Discussion}

Cabbage BR symptoms started at 28 and 21 DPI in the present study. This is later than the 10 to $14 \mathrm{~d}$ previously described in greenhouse studies (Williams, 1980), indicating that
BR symptoms development in cabbage after inoculation with $X c c$ under field conditions may be different from in a greenhouse environment (Griffiths and Roe, 2005).

Low temperatures later in Fall 2018 extended the development of the cabbage crop, which corroborated the results of Paranhos et al. (2016). However, the low temperatures were not sufficient to suppress cabbage BR severity. In contrast, the extended period of crop development increased the window for the occurrence of rain events, which favors $X c c$ development and increased both cabbage BR severity and the AUDPC of cabbage BR compared with Spring 2019 (Vicente and Holub, 2013). When environmental conditions were favorable for $X c c$ development, which could increase the severity of BR in late Spring 2019, cabbage heads were near maturity and were being harvested. The low temperatures early in spring may slow development of $X c c$ infection. Conversely, the high temperatures at the beginning of the fall season may increase $X c c$ development rates, resulting in earlier plant infection impacting BR symptom severity. Therefore, planting date may be a tool used to reduce BR severity in the southeastern United States and ultimately increase marketable yields (Jensen et al., 2005; Paranhos et al., 2016).

Although severity of BR symptoms was higher in Fall 2018 compared with Spring 2019, all cultivars had symptoms of BR in both growing seasons. Results suggested that cultivars TCA-549 and Capture had the lowest susceptibility against $X c c$ under growing conditions present in this study. Both cultivars presented few BR symptoms and the lowest AUDPC, but TCA-549 had greater marketable yields than Capture. Under conditions of low disease, cultivars with a low susceptibility against $X c c$ have been reported to have lower yields than those with less disease tolerance due to a lack of adaptation to climatic conditions in the studied region (Jensen et al., 2005). 'Acclaim' had the highest marketable yield; nonetheless, 'Acclaim' had a high susceptibility against $X c c$ by presenting a high severity of BR symptoms. Overall, correlations suggested that an increase in BR severity in cabbage plants may reduce head weight, consequently reducing cabbage marketability.

Cabbage cultivar inheritance for $\mathrm{BR}$ resistance has been thoroughly studied, but a resistance gene(s) has not yet been identified (Vicente and Holub, 2013). Although cultivar resistance against $X c c$ may be the most effective method of control for $\mathrm{BR}$ (Afrin et al., 2018; Krauthausen et al., 2011 ; Roberts and Koenraadt, 2006; Schaad and Alvarez, 1993; Taylor et al., 2002), in practice, success has been limited. The use of more tolerant cultivars combined with pathogen-free seeds (Krauthausen et al., 2011; Schaad and Alvarez, 1993), crop rotation (Arias et al., 2000), and the adoption of effective spraying programs, should then be considered the best management practice for cabbage BR disease management.

\section{Conclusions}

There have been several studies evaluating the resistance of cabbage against $X c c$ as well as factors that affect cabbage BR disease severity; however, many of these studies were conducted under greenhouse conditions. The present study evaluated commercial cabbage cultivars with tolerance against Xcc under field conditions in southeastern United States, 

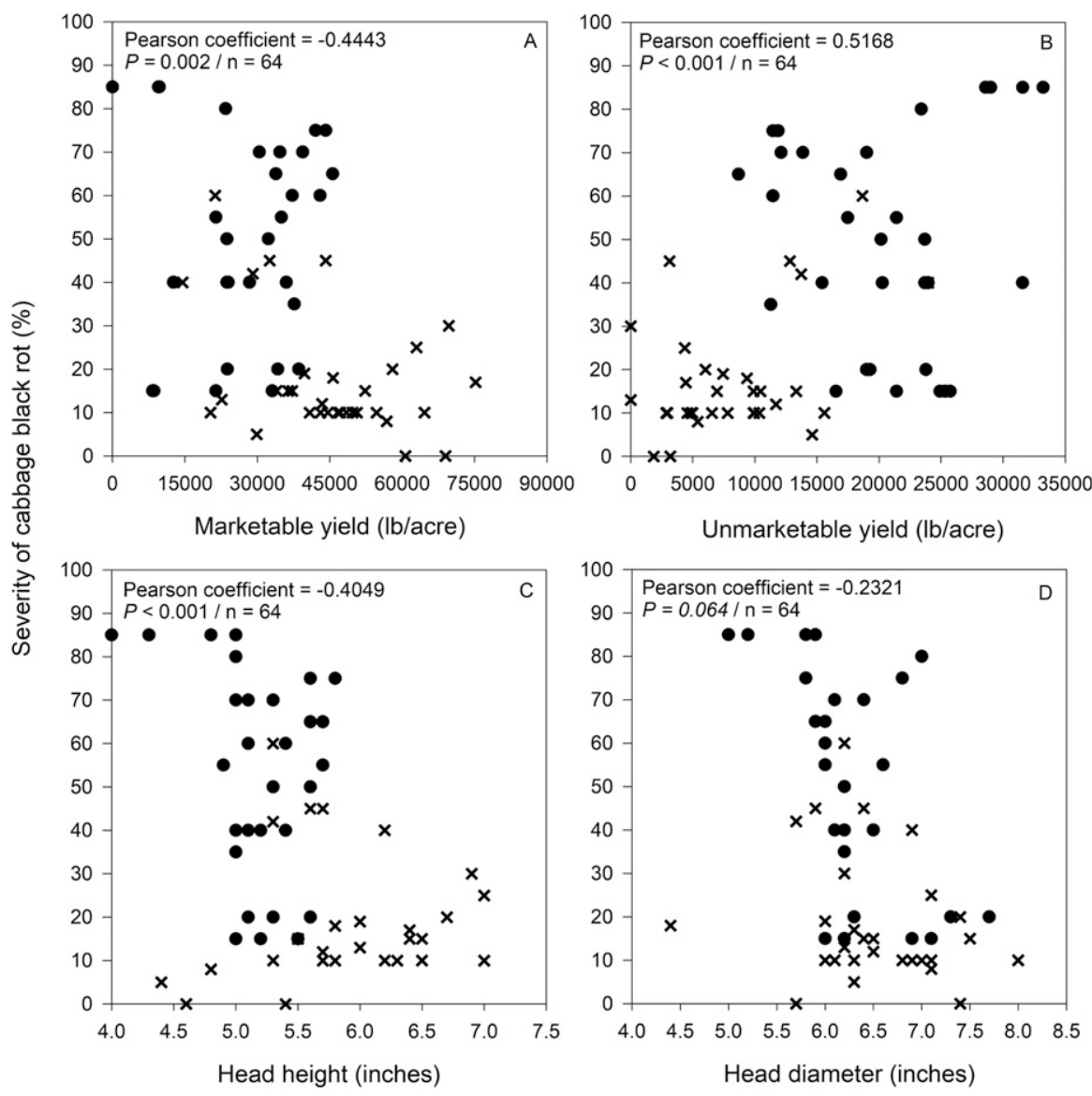

- Fall $2018 \times$ Spring 2019

Fig. 4. Correlation between the severity of cabbage black rot and marketable yield (A), unmarketable yield (B), head height (C), and head diameter (D) during Fall 2018 and Spring 2019 cabbage seasons for Tifton, GA; $1 \mathrm{lb} / \mathrm{acre}=1.209 \mathrm{~kg} \cdot \mathrm{ha}^{-1}$, 1 inch $=2.54 \mathrm{~cm}$.

to determine the impact of cultivar and disease severity on cabbage yield and head quality. In general, cabbage grown in Fall 2018 had a higher severity of BR symptoms compared with cabbage grown in Spring 2019, mostly due to favorable weather conditions for disease development in the fall. Although BR symptoms were present in all cultivars for both growing seasons, TCA-549 had the lowest severity of BR symptoms while maintaining high marketable yields. Future studies may seek to investigate the effect of planting dates on black rot severity within both cabbage growing season (i.e., fall and spring), this would help to account for the weather variability on the interaction of disease and crop development.

\section{Literature cited}

Afrin, K.S., M.A. Rahim, J.I. Park, S. Natarajan, H.T. Kim, and I.S. Nou. 2018.
Identification of NBS-encoding genes linked to black rot resistance in cabbage (Brassica oleracea var. capitata). Mol.

Arias, R.S., S.C. Nelson, and A.M. Alvarez. 2000. Effect of soil-matric potential and phylloplanes of rotation-crops on the survival of a bioluminescent Xanthomonas campestris pv. campestris. Eur. J. Plant Pathol. 106:109-116.

Bowley, S. 2015. A hitchhiker's guide to statistics in biology. Generalized linear mixed model edition. Plants, Kincardine, ON, Canada.

Campbell, C.L. and L.V. Madden. 1990. Introduction to plant disease epidemiology. Wiley, New York, NY.

Cook, A.A., J.C. Walker, and R. Larson. 1952. Studies on the disease cycle of black rot of crucifers. Phytopathology 42:162167.

da Silva, A.L.B.R., T. Coolong, and E. Smith. 2019. Irrigating app. 30 Aug. 2018. <www.irrigating.uga.edu>. Biol. Rep. 45:773-785.
Griffiths, P.D. and C. Roe. 2005. Response of Brassica oleracea var. capitata to wound and spray inoculations with Xanthomonas campestris pv. campestris. HortScience 40:47-49.

Jensen, B.D., S.M. Massomo, I.S. Swai, J. Hockenhull, and S.B. Andersen. 2005. Field evaluation for resistance to the black rot pathogen Xanthomonas campestris pv. campestris in cabbage (Brassica oleracea). Eur. J. Plant Pathol. 113:297-308.

Kocks, C.G. and M.A. Ruissen. 1996. Measuring field resistance of cabbage cultivars to black rot. Euphytica 91:45-53.

Köppen, W. 1931. Grundriss der Klimakunde. Walter de Gruyter, Berlin, Germany.

Krauthausen, H.J., N. Laun, and W. Wohanka. 2011. Methods to reduce the spread of the black rot pathogen, Xanthomonas campestris pv. campestris, in Brassica transplants. J. Plant Dis. Prot. 118:7-16.

Little, E.L. 2019. 2016 Georgia plant disease loss estimates. Univ. Georgia Coop. Ext. Serv. Bul. AP 102-9.

Lema, M., P. Soengas, P. Velasco, M. Francisco, and M. Cartea. 2011. Identification of sources of resistance to Xanthomonas campestris pv. campestris in Brassica napus crops. Plant Dis. 95:292297.

Massomo, S.M.S., R.B. Mabagala, I.S. Swai, J. Hockenhull, and C.N. Mortensen. 2004. Evaluation of varietal resistance in cabbage against the black rot pathogen, Xanthomonas campestris pv. campestris in Tanzania. Crop Prot. 23:315-325.

Meenu, G., A. Vikram, and N. Bharat. 2013. Black rot-a devastating disease of crucifers: A review. Agr. Rev. 34:269-278.

Paranhos, L.G., C.E. Barrett, L. Zotarelli, R. Darnell, K. Migliaccio, and T. Borisova. 2016. Planting date and in-row plant spacing effects on growth and yield of cabbage under plastic mulch. Scientia Hort. 202:49-56.

Park, Y.J., B.M. Lee, J. Ho-Hahn, G.B. Lee, and D.S. Park. 2004. Sensitive and specific detection of Xanthomonas campestris pv. campestris by PCR using species-specific primers based on hrpF gene sequences. Microbiol. Res. 159:419-423.

Peňázová, E., T. Kopta, M. Jurica, J. Pečenka, A. Eichmeier, and R. Pokluda. 2018. Testing of inoculation methods and susceptibility testing of perspective cabbage breeding lines (Brassica oleracea var. capitata) to the black rot disease caused by Xanthomonas campestris pv. campestris. Acta Univ. Agr. Silvic. Mendel. Brun. 66:139-148. 
Roberts, S.J. and H. Koenraadt. 2006. Detection of Xanthomonas campestris pv. campestris on Brassica spp., p. 1-16. In: International rules for seed testing. Intl. Seed Testing Assn. (ISTA), Bassersdorf, Switzerland.

Roberts, S.J., J. Brough, and P.J. Hunter. 2007. Modelling the spread of Xanthomonas campestris pv. campestris in moduleraised Brassica transplants. Plant Pathol. 56:391-401.

Saha, P., P. Kalia, M. Sharma, and D. Singh. 2016. New source of black rot disease resistance in Brassica oleracea and genetic analysis of resistance. Euphytica 207:35-48.

Schaad, N.W. and A. Alvarez. 1993. Xanthomonas campestris pv. campestris: Cause of black rot of crucifers, p. 51-55. In: J. Swings and L. Civetta (eds.). Xanthomonas. Springer, Berlin, Germany.
Shimelis, H. 2005. Response of cabbage cultivars to black rot infection. Afr. Crop Sci. J. 13:185-192.

Taylor, J.D., J. Conway, S.J. Roberts, D. Astley, and J.G. Vicente. 2002. Sources and origin of resistance to Xanthomonas campestris pv. campestris in Brassica genomes. Phytopathology 92:105-111.

University of Georgia. 2019. Tifton, Georgia climate data. 1 Sept. 2019. <http://www. georgiaweather.net/?content $=$ calculator\& variable $=\mathrm{CC} \&$ site $=$ TIFTON $>$.

U.S. Department of Agriculture. 1983. Soil survey. Web soil survey-soil survey of Tift County, Georgia. 23 Aug. 2019. <https://websoilsurvey.sc.egov.usda. gov/App/WebSoilSurvey.aspx>.
Vicente, J.G., J. Conway, S. Roberts, and J. Taylor. 2001. Identification and origin of Xanthomonas campestris pv. campestris races and related pathovars. Phytopathology 91:492-499.

Vicente, J.G. and E.B. Holub. 2013. Xanthomonas campestris pv. campestris (cause of black rot of crucifers) in the genomic era is still a worldwide threat to Brassica crops. Mol. Plant Pathol. 14:218.

Vicente, J.G., J.D. Taylor, A.G. Sharpe, I.A.P. Parkin, D.J. Lydiate, and G.J. King. 2002. Inheritance of race-specific resistance to Xanthomonas campestris pv. campestris in Brassica genomes. Phytopathology 92:1134-1141.

Williams, P.H. 1980. Black rot: A continuing threat to world crucifers. Plant Dis. 64:736-742.

Wolfe, K.L. and K. Stubbs. 2018. Georgia farm gate value report 2017. Univ. Georgia Coop. Ext. Surv. Bul. AR 17-01. 